\title{
Fine-scale variability in methanol uptake and oxidation: from the microlayer to $1000 \mathrm{~m}$
}

\author{
J. L. Dixon and P. D. Nightingale \\ Plymouth Marine Laboratory, Prospect Place, West Hoe, Plymouth, Devon, PL1 3DH, UK \\ Correspondence to: J. L. Dixon (jod@pml.ac.uk)
}

Received: 22 March 2012 - Published in Biogeosciences Discuss.: 16 April 2012

Revised: 19 June 2012 - Accepted: 30 June 2012 - Published: 6 August 2012

\begin{abstract}
The aim of this research was to make the first depth profiles of the microbial assimilation of methanol carbon and its oxidation to carbon dioxide and use as an energy source from the microlayer to $1000 \mathrm{~m}$. Some of the highest reported methanol oxidation rate constants of $0.5-$ $0.6 \mathrm{~d}^{-1}$ were occasionally found in the microlayer and immediately underlying waters $(10 \mathrm{~cm}$ depth), albeit these samples also showed the greatest heterogeneity compared to other depths down to $1000 \mathrm{~m}$. Methanol uptake into the particulate phase was exceptionally low in microlayer samples, suggesting that any methanol utilised by microbes in this environment is for energy generation. The sea surface microlayer and $10 \mathrm{~cm}$ depth also showed a higher proportion of bacteria with a low DNA content, and bacterial leucine uptake rates in surface microlayer samples were either less than or the same as those in the underlying $10 \mathrm{~cm}$ layer. The average methanol oxidation and particulate rates were however statistically the same throughout the depths sampled, although the latter were highly variable in the near-surface $0.25-2 \mathrm{~m}$ compared to deeper depths. The statistically significant relationship demonstrated between uptake of methanol into particles and bacterial leucine incorporation suggests that many heterotrophic bacteria could be using methanol carbon for cellular growth. On average, methanol bacterial growth efficiency $\left(\mathrm{BGE}_{\mathrm{m}}\right)$ in the top $25 \mathrm{~m}$ of the water column is $6 \%$ and decreases with depth. Although, for microlayer and $10 \mathrm{~cm}$-depth samples, $\mathrm{BGE}_{\mathrm{m}}$ is less than the near-surface $25-217 \mathrm{~cm}$, possibly reflecting increased environmental UV stress resulting in increased maintenance costs, i.e. energy required for survival. We conclude that microbial methanol uptake rates, i.e. loss from seawater, are highly variable, particularly close to the seawater surface, which could significantly impact upon seawater concentrations and hence the air-sea flux.
\end{abstract}

\section{Introduction}

Oxygen-containing volatile organic species (OVOCs), such as low-molecular-weight alcohols, aldehydes and ketones, substantially influence the oxidising capacity and ozoneforming potential of the atmosphere (Singh et al., 2001 and references therein). Methanol is the predominant OVOC in the troposphere (Singh et al., 2000, 2001) and the second most abundant organic gas after methane (Jacob et al., 2005) with atmospheric ubiquity (Singh et al., 2000). However, there is still considerable uncertainty over sources of all OVOCs, and, critically, we continue to be unsure of the importance of the oceans in controlling the abundance of these compounds in marine air (Singh et al., 2001, 2003; Williams et al., 2004; Lewis et al., 2005; Beale et al., 2010). The surface ocean is thought to play an important role in the budget of methanol, and atmospheric observations in combination with air-sea exchange models generally predict an air-to-sea flux of varying magnitude (e.g. Singh et al., 2001, 2003; Sinha et al., 2007; Carpenter et al., 2004; Williams et al., 2004; Dixon et al., 2011a). These studies have generally used a surface methanol concentration of the order $100 \mathrm{nM}$, but recent seawater analysis, using a membrane inlet-proton transfer reaction mass spectrometry, has shown concentrations up to $429 \mathrm{nM}$ (Beale et al., 2011). Recent flux calculations in the oligotrophic North Atlantic suggest that the atmosphere is unlikely to be a dominant source of methanol and invoke in situ production mechanisms (Dixon et al, 2011b). The measured seawater concentration of methanol is a product of its sources, e.g. production mechanisms and rates and sinks. Methylotrophic organisms by definition must use one-carbon compounds more reduced than $\mathrm{CO}_{2}$, like methanol, as sole energy sources and for assimilation of carbon into cell biomass (Murrell and 
McDonald, 2000; Chistoserdova, 2011). Biological methanol turnover times as low as 1 day have been found in surface waters of the subtropical northeast Atlantic (Dixon et al., 2011a). Molecular approaches have identified methylotrophs like Hyphomicrobium and Methylophaga spp. in remote marine and coastal locations (Dixon et al., 2011b; Neufield et al., 2007, 2008). Other bacteria, such as undescribed Gammaproteobacteria (Neufield et al., 2007, 2008), have also been found to uptake methanol carbon into their cells. Recently, Sun et al. (2011) also revealed that the most abundant heterotrophs in the oceans, SAR11 Alphaproteobacteria, who play a major role in mineralising marine-dissolved organic matter, use methanol to produce energy.

Previous results have focussed only on bulk surface waters $(5-10 \mathrm{~m})$ and have reported microbial methanol oxidation rates between $2-8 \mathrm{nM} \mathrm{d}^{-1}$ in more northern temperate waters (Dixon et al., 2011b) and between $2-146 \mathrm{nM} \mathrm{d}^{-1}$ in oligotrophic tropical waters of the North Atlantic (Dixon et al., 2011a), giving turnover times of between 7-33 and 1-25 days, respectively. The aim of this research was to make the first depth profiles for microbial methanol use as an energy source and a growth substrate. We further profiled the finescale variability in these rates in the top $2 \mathrm{~m}$ of the water column and the sea surface microlayer to assess whether bulk surface, i.e. 5-10 m measurements, typically used in airsea flux calculations, were truly representative of the nearsurface $(<2 \mathrm{~m})$. Temporal and surface spatial changes in microbial methanol use are also compared.

\section{Methods}

Sampling was conducted at a series of stations west of the Iberian Peninsula in the NE Atlantic aboard RRS Discovery on the SOLAS UK (Surface Ocean Lower Atmosphere Study) DOGEE II (Deep Ocean Gas Exchange Experiment II) D320 research cruise (Fig. 1).

\subsection{Sampling devices}

Ten-litre, Teflon-coated, steel-sprung Niskin bottles were used to routinely sample waters $\geq 5 \mathrm{~m}$ during spatial and depth surveys. High-resolution sampling in the top $2 \mathrm{~m}$ was achieved through the use of a Near-surface Sampling Device $(\mathrm{N})$, which consists of eight 41 sampling bottles mounted horizontally and spaced at $20-30 \mathrm{~cm}$ intervals, with the top bottle at $25 \mathrm{~cm}$ below the sea surface and the bottom one at $220 \mathrm{~cm}$ (as described in Tilstone et al., 2010). An additional microlayer sampling device that was mounted on a Catamaran (C) was also fitted with a subsurface pole that enabled sampling from $10 \mathrm{~cm}, 1$ and $2 \mathrm{~m}$ below the sea surface (as described in Brooks et al., 2009). The sea surface microlayer was also sampled by hand from a rigid inflatable boat using a Garrett Screen (GS, Garrett 1965). Briefly, this screen consisted of a $50 \mathrm{~cm}^{2}$ frame enclosing a stainless steel mesh and

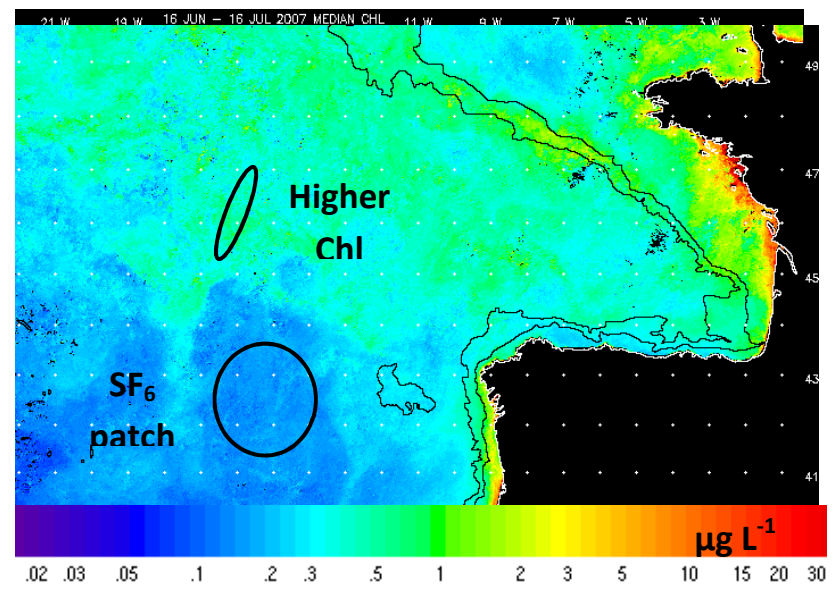

Fig. 1. Sampling areas overlaid on a composite chlorophyll $a$ image (MODIS Aqua) over the duration of the cruise (16 June-16 July 2007).

is typically considered to sample the top $300-400 \mu \mathrm{m}$ (Cunliffe et al., 2009; Zuev et al., 2001). Additional $10 \mathrm{~cm}$ samples were also taken by hand from the inflatable boat using a $10 \mathrm{ml}$ long-handled pipette. Microlayer samples were also obtained using the Catamaran, as it was fitted with a rotating drum device mounted between the hulls. The rotating glass drum picks up the sea surface by tension, and is thought to typically sample $20-100 \mu \mathrm{m}$ (Zuev et al., 2001).

\section{2 $\mathrm{SF}_{6}$ tracer deployment}

A diel experiment was undertaken using surface waters that had been labelled with the inert tracer $\mathrm{SF}_{6}$ (as used in an airsea gas transfer experiment detailed in Salter et al., 2011). We used this tracer to check that we were consistently sampling the same body of water during the diel experiment.

\subsection{Methanol oxidation and uptake into particulate phase}

We incubated surface seawater samples with nanomolar concentrations of ${ }^{14} \mathrm{C}$-labelled methanol $\left({ }^{14} \mathrm{CH}_{3} \mathrm{OH}\right)$ and determined both uptake into particles and oxidation to $\mathrm{CO}_{2}$ (Dixon et al., 2011a and b), which we interpret as microbial cellular incorporation (cell growth, $G$ ) and energy use (E), respectively. For full experimental details please refer to Dixon et al., 2011b. In brief, seawater samples were treated with approximately $10 \mathrm{nM}$ final added concentration of ${ }^{14} \mathrm{CH}_{3} \mathrm{OH}$, and were always $<1 \%$ of the sample volume. We generally incubated oxidation samples for $1-3 \mathrm{~h}$ and uptake onto particles for 3-9h (to ensure sufficient counts).

The data are reported as apparent rate constants, $k\left(\mathrm{~h}^{-1}\right)$ calculated from a ratio of the sample ${ }^{14} \mathrm{C}$ counts (from the particles on the filter or from the precipitate which contains the captured ${ }^{14} \mathrm{CO}_{2}$ as $\mathrm{Sr}^{14} \mathrm{CO}_{3}, \mathrm{nCi} \mathrm{ml}^{-1} \mathrm{~h}^{-1}$ ) divided by total ${ }^{14} \mathrm{CH}_{3} \mathrm{OH}$ added to the sample $\left(\mathrm{nCi} \mathrm{ml}^{-1}\right)$. All rate 
Table 1. Summary of methanol uptake and cellular abundance in the microlayer and $10 \mathrm{~cm}$-depth layer in the low chlorophyll $a$ tracer $\left(\mathrm{SF}_{6}\right)$ patch area. Error bars are based on 2-6 replicates.

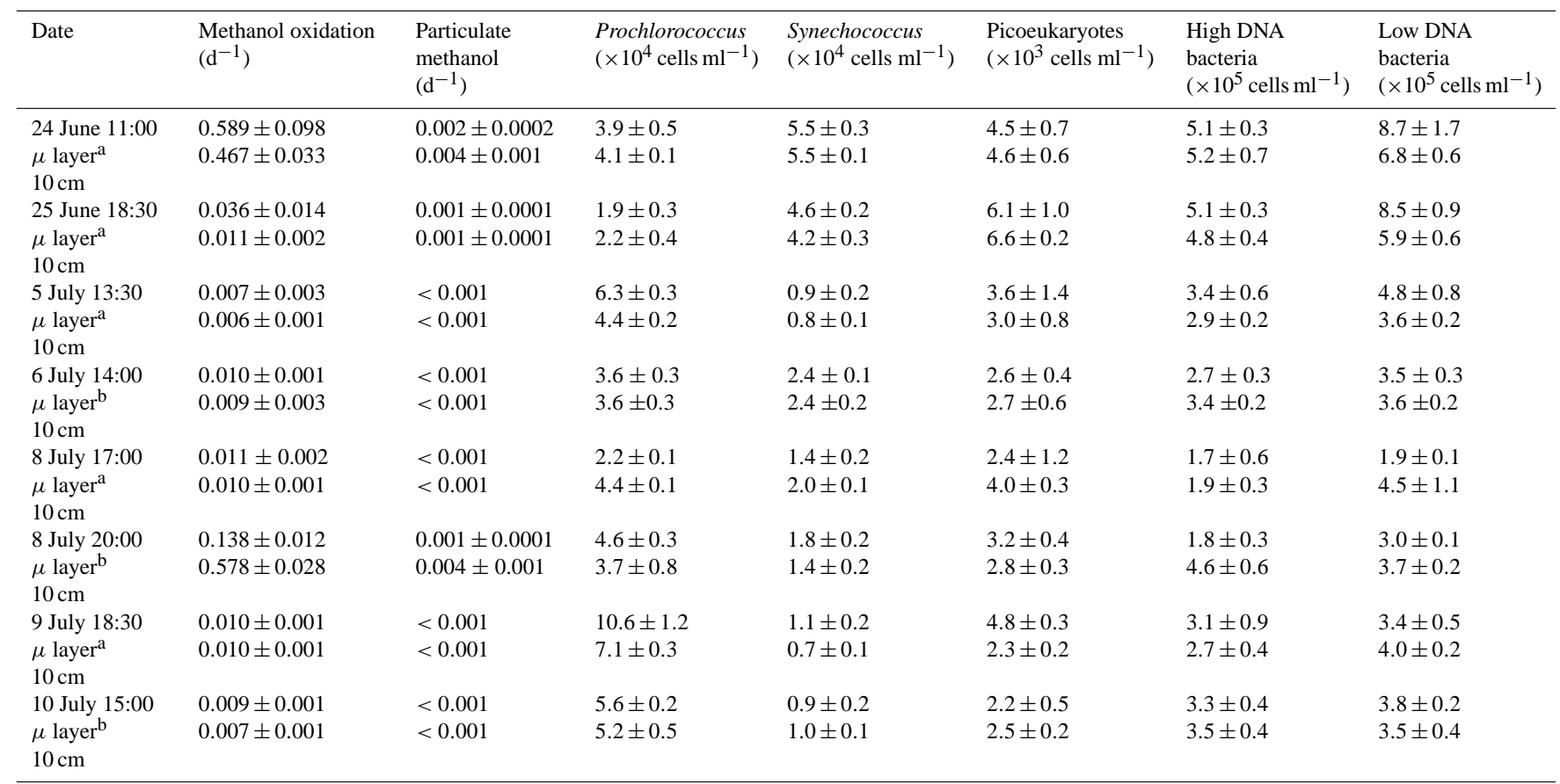

a The microlayer was sampled using a Garrett Screen and $10 \mathrm{~cm}$ using a hand pipette from a rib.

${ }^{b}$ The microlayer was sampled using a rotating skimmer device and the $10 \mathrm{~cm}$ layer using a subsurface pole mounted on a Catamaran.

constants were corrected by subtracting killed sample (TCA, $5 \%$ final concentration) counts. Evaluation of control samples suggests that $\leq 2 \%$ of the added ${ }^{14} \mathrm{CH}_{3} \mathrm{OH}$ is counted in the resultant precipitate (for determining oxidation) and $\leq 0.3 \%$ is recovered on the filters.

\subsection{Bacterial production}

Heterotrophic bacterial production rates were determined by measuring the incorporation of ${ }^{3} \mathrm{H}$-leucine $(20 \mathrm{nM}$ final concentration) into bacterial protein synthesis on $1.7 \mathrm{ml}$ seawater samples following the method of Smith and Azam (1992).

\subsection{Cellular abundance}

The numbers of bacterioplankton cells were determined by flow cytometry on SYBR Green I DNA-stained cells from $1.8 \mathrm{ml}$ seawater samples fixed in paraformaldehyde $(5 \%$, final concentration). Numbers of Prochlorococcus spp. and Synechococcus spp. were analysed on unstained samples by flow cytometry. Surface concentrations of chlorophyll $a$ were estimated using a composite Aqua-MODIS chlorophyll $a$ remotely-sensed image for stations 4 and 5, as unfortunately the continuous surface fluorometer onboard the ship was not working correctly.

\section{Results}

\subsection{The sea surface microlayer and $10 \mathrm{~cm}$}

Methanol oxidation rate constants in the sea surface microlayer were highly variable and on average ranged between $0.006-0.59 \mathrm{~d}^{-1}$ (Table 1). Methanol uptake into the particulate phase in the microlayer showed the lowest-ever rate constants reported, and on average ranged between $<0.001-$ $0.002 \mathrm{~d}^{-1}$ (Table 1). The highest values of uptake were coincident with the highest methanol oxidation rates. For the majority of sampling occasions there was little difference between methanol rate constants (oxidation and particulate uptake) in the sea surface microlayer and $10 \mathrm{~cm}$ depth. The greatest difference in oxidation and uptake rates between the microlayer and $10 \mathrm{~cm}$ samples was observed at times of maximum rates, although there was no consistent trend. However, the two highest particulate methanol rate constants were found in the $10 \mathrm{~cm}$-depth samples (not the microlayer). For microlayer samples which were obtained with either the Garrett Screen and/or the Catamaran Skimmer, no consistent differences could be identified for any parameter/rate determined.

Numbers of Prochlorococcus cells on average ranged be-

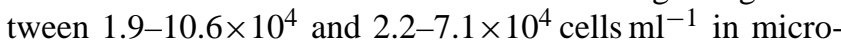
layer and $10 \mathrm{~cm}$-depth samples, respectively (Table 1). The highest biomass of Prochlorococcus cells was shown in a 

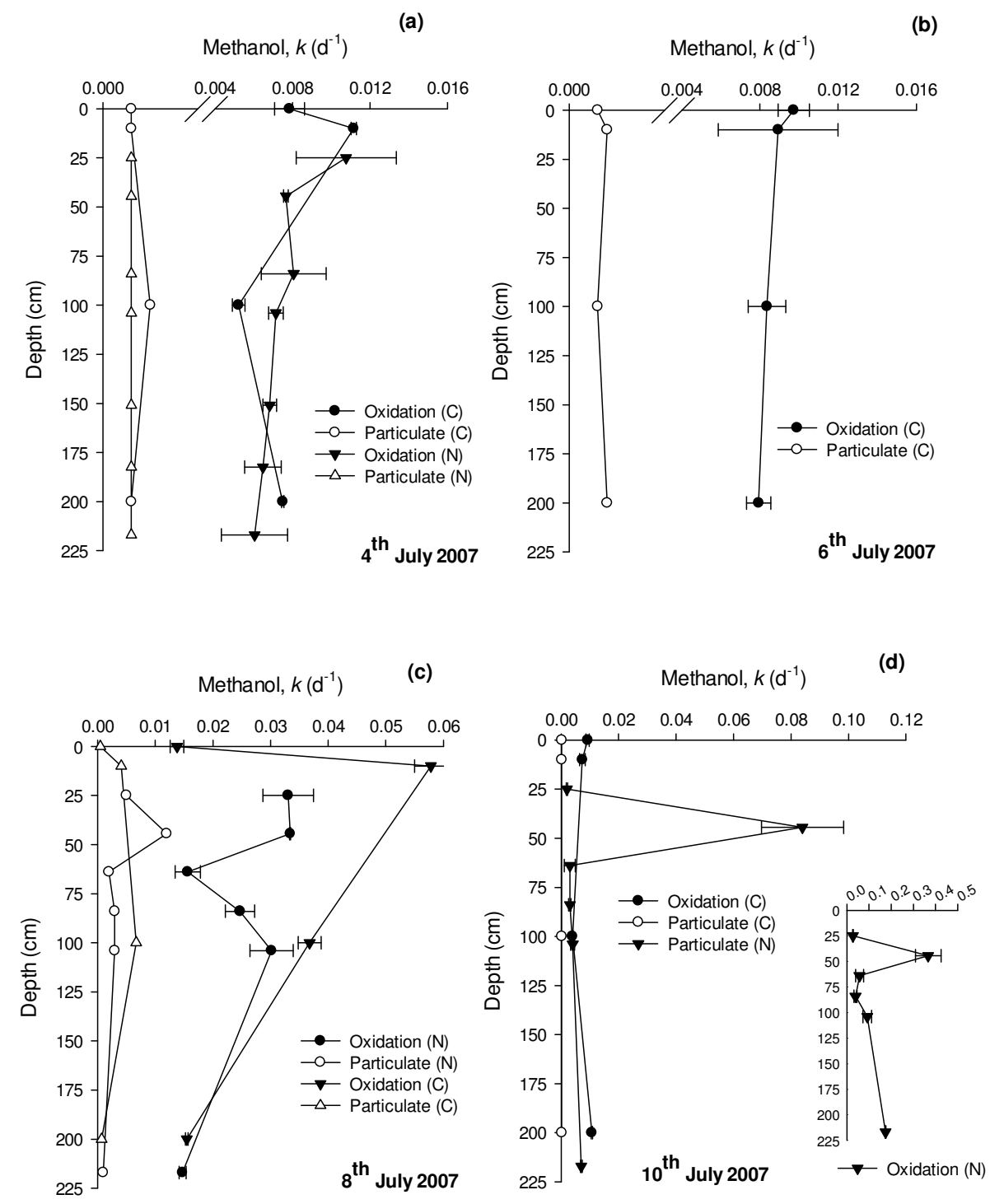

Fig. 2. Fine-scale variability in methanol oxidation and uptake into particles $(k)$ in the top $2 \mathrm{~m}$ of the water column as sampled by either the Near-surface Sampling Device (N) or the Catamaran (C) for profiles sampled on (a) 4 July, (b) 6 July, (c) 8 July and (d) 10 July 2007 . The error bars represent \pm 1 standard deviation based on at least 3 replicates.

microlayer sample. Numbers of Synechococcus cells ranged between $0.9-5.5 \times 10^{4}$ and $0.7-5.5 \times 10^{4}$ cells ml $^{-1}$ in microlayer and $10 \mathrm{~cm}$-depth samples, respectively (Table 1), whilst picoeukaryotic cells ranged between $2.2-6.6 \times 10^{3}$ cells ml $^{-1}$ (Table 1). In general, cell numbers showed no convincing differences or trends between microlayer and $10 \mathrm{~cm}$ samples.

Bacterial numbers (high and low DNA) ranged between $3.6-13.8 \times 10^{5}$ cells ml $^{-1}$ and $4.7-12.1 \times 10^{5}$ cells ml $^{-1}$ in microlayer and $10 \mathrm{~cm}$-depth samples, respectively, and were highest in both during sampling times in June, compared to July (Table 1). However, there was no overall trend in bacterial numbers between the microlayer and $10 \mathrm{~cm}$-depth samples. There was however a greater number of bacteria (52$64 \%$ ) containing a relatively low DNA content compared to a high DNA content (as seen on the Flow Cytometer, Table 1) for all surface microlayer samples. Bacterial numbers from $10 \mathrm{~cm}$ depth showed more variability in the proportion of low DNA-containing bacteria (44-71\%). Correlations showed statistically significant relationships between both methanol oxidation and uptake into particles with the numbers of low DNA-containing heterotrophic bacteria in the microlayer samples $(n=11, r=0.6189, p \leq 0.05$ and $r=0.7166, p \leq 0.02$, respectively). But for samples from $10 \mathrm{~cm}$, the only statistically significant correlations were found between methanol oxidation and uptake into particles with the numbers of high DNA-containing heterotrophic bacteria $(n=9, r=0.6681, p \leq 0.05$ and $r=0.7518, p \leq 0.02$, respectively). 


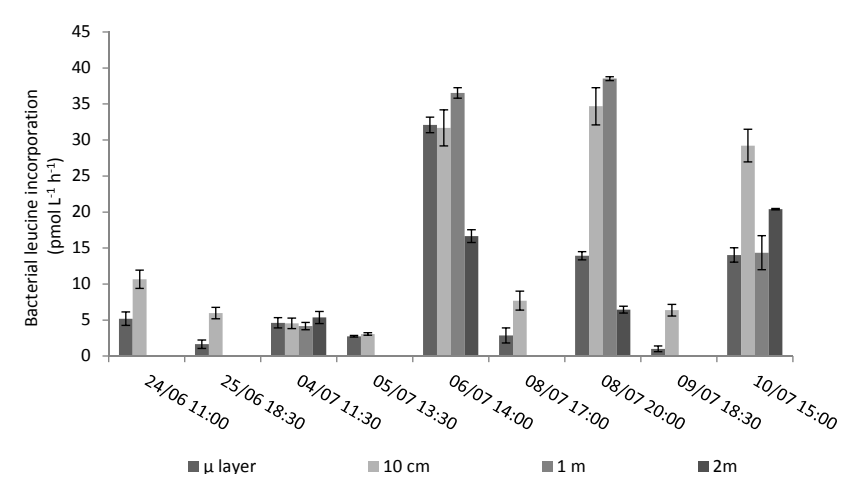

Fig. 3. Variability in bacterial leucine incorporation for microlayer, $10 \mathrm{~cm}, 1$ and $2 \mathrm{~m}$ depths, where error bars denote $\pm 1 \mathrm{sd}$ based on three replicates.

\subsection{Depth variability in the top $2 \mathrm{~m}$}

High depth-resolution sampling in the top $2 \mathrm{~m}$ of the water column often revealed significant differences in both methanol oxidation and uptake into particles between samples that were as little as $25 \mathrm{~cm}$ depth apart (Fig. 2), illustrating the heterogenic nature of microbial methanol use. Hot spots or peaks in activity were often seen at depths just below the surface $\leq 50 \mathrm{~cm}$, e.g. on 10 July 2007 (Fig. 2d). The average proportion of methanol used for energy compared to growth $(\mathrm{E}: \mathrm{G})$ in the top $2 \mathrm{~m}$ was 22 , in agreement with more traditionally sampled surface $(\sim 5 \mathrm{~m})$ values. However, lower E: G values between 3-10 were sometimes observed between depths of 45-100 cm, e.g. on 8 July 2007 (N profile, Fig. 2c), indicating that on occasion relatively more methanol was used for growth. This ratio was more similar to that observed in coastal and shelf sea surface waters (Dixon et al., 2011b).

Bacterial leucine incorporation was also compared in surface microlayer $\left(1-32 \mathrm{pmol}^{-1} \mathrm{~h}^{-1}\right), 10 \mathrm{~cm}$ (3$\left.34 \mathrm{pmoll}^{-1} \mathrm{~h}^{-1}\right), 1 \mathrm{~m}\left(4-39 \mathrm{pmoll}^{-1} \mathrm{~h}^{-1}\right)$, and $2 \mathrm{~m} \mathrm{(5-}$ $20 \mathrm{pmoll}^{-1} \mathrm{~h}^{-1}$ ) depths (Fig. 3). Surface microlayer samples almost consistently showed values lower than samples from $10-100 \mathrm{~cm}$, except for 4-5 July 2007, which showed no statistically significant differences in the top $2 \mathrm{~m}$.

\subsection{Vertical profiles from $\mathbf{5}-\mathbf{1 0 0 0} \mathrm{m}$}

Depth profiles of methanol oxidation and uptake into cells showed considerable changes with depth, sometimes showing subsurface maxima between $20-30 \mathrm{~m}$ (Fig. 4). However, some of the biggest changes were shown between sampling days. For example, methanol oxidation rates generally varied between $0.007-0.09 \mathrm{~d}^{-1}$ (Fig. 4a, average 0.02, $n=22$ ) between $5-1000 \mathrm{~m}$, but on 27 June 2007 increased by over an order of magnitude to between $0.25-0.36 \mathrm{~d}^{-1}$ (average $0.30, n=3$ ), with a surface maximum. Likewise incorporation of methanol into cells for growth generally varied between $<0.001-0.0016 \mathrm{~d}^{-1}$ (Fig. 4c, average 0.001, $n=28$ ),
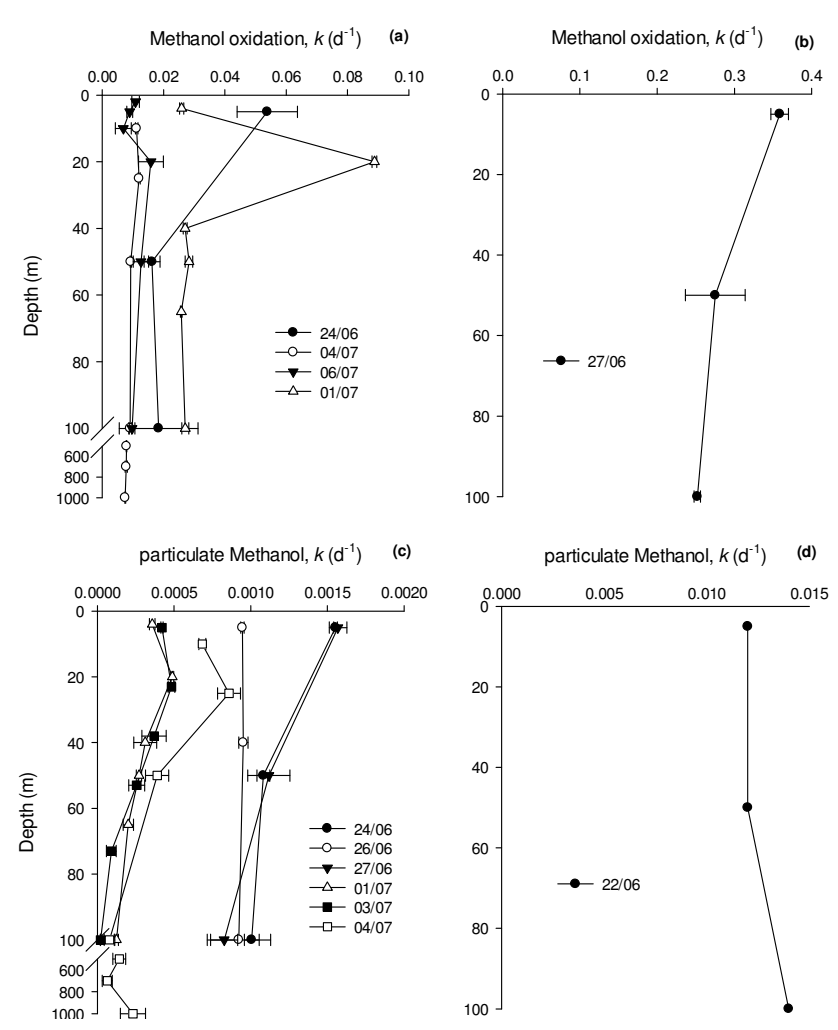

Fig. 4. Depth profiles of apparent rate constants $(k)$ for (a and b) methanol oxidation and (c and $\mathbf{d})$ uptake into the particulate phase.

but was more than one order of magnitude greater on 22 June 2007 with an average of $0.013 \mathrm{~d}^{-1}(n=3)$. We do not have methanol oxidation rates on this day to compare with. These sporadic increases in rates are currently not understood. The average E:G over all depths was $106(n=19$, range 14-305), which decreased to an average of 85 ( $n=9$, range 14-229) for samples from the top mixed layer varying between 30$53 \mathrm{~m}$, which is within the range previously reported (Dixon et al., 2011a and b).

For deep samples collected between $500-1000 \mathrm{~m}$ on 1 July 2007, methanol oxidation and uptake into particle rate constants were low and varied between $0.008 \pm 0.0002$ and $0.0001 \pm 0.0001 \mathrm{~d}^{-1}(n=3)$, respectively, with an average energy to growth ratio of 70 .

\subsection{Diel variability}

The diel experiment was carried out in a patch of water that had been labelled with the inert tracer $\mathrm{SF}_{6}$. Surface concentrations of $\mathrm{SF}_{6}$ started to consistently decrease from midnight to around 04:00 GMT (Fig. 5a). Winds strengthened from 20 to 30 knots during this period and we were unable to navigate back towards the assumed patch centre. Methanol oxidation rate constants varied between $2.8-9.7 \times 10^{-4} \mathrm{~h}^{-1}$, showing maximum rates just after dawn (07:00 GMT) and minimum rates in the middle of the night (03:00 GMT), although 


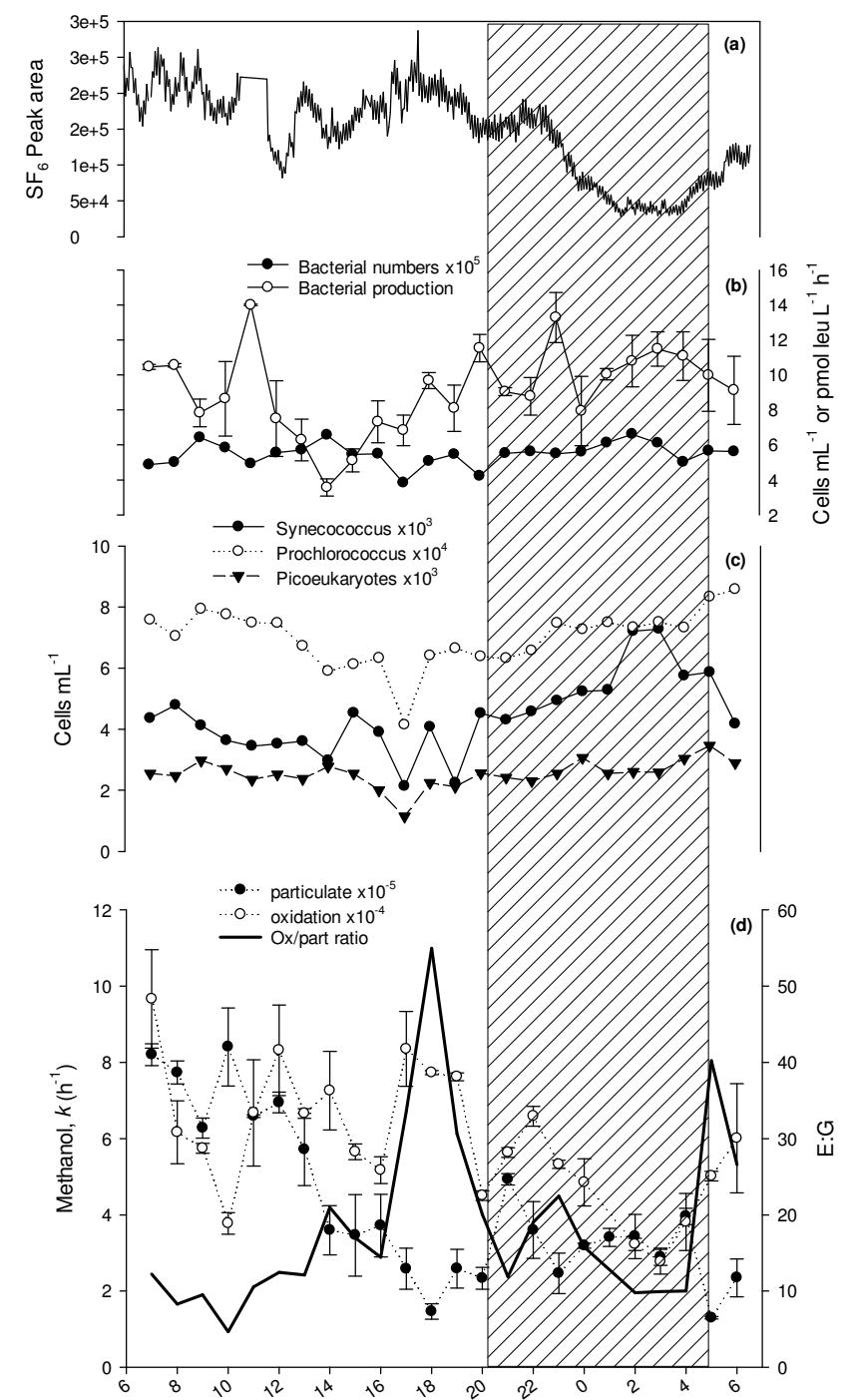

Fig. 5. Diel variability in (a) concentration of inert tracer $\mathrm{SF}_{6}$, (b) bacterial leucine incorporation and numbers of bacteria, (c) numbers of Synechococcus, Prochlorococcus and Picoeukaryotes and (d) apparent rate constant $(k)$ of methanol oxidation and uptake into cellular material with the microbial E:G, where the hashed area indicates hours of darkness. Error bars are based on at least 3 replicates.

the latter could have been a result of spatial sampling variability due to station drift. However, there was no consistent trend evident for methanol oxidation rates over the diel cycle, unlike microbial uptake of methanol into the particulate phase, which showed a decreasing trend from 07:00 to 18:00 GMT during daylight hours (Fig. 5d). Methanol cellular incorporation rates were approximately an order of magnitude lower than those for microbial methanol energy use, and varied between $1.3-8.4 \times 10^{-5} \mathrm{~h}^{-1}$. Maximum rates were shown at 10:00 GMT, and minimum rates just before dawn at 05:00 GMT, both 2-3 $\mathrm{h}$ after the respective methanol oxidation rates. The ratio of methanol used for microbial energy compared to growth ranged between 5-55 over the diel cycle. Two maximums in this ratio were observed almost $12 \mathrm{~h}$ apart at 18:00 and 05:00 GMT.

Numbers of heterotrophic bacteria, picoeukaryotes, Prochlorococcus and Synechococcus cells ranged between $3.8-6.6 \times 10^{5}, \quad 1.1-3.5 \times 10^{3}, \quad 4.1-8.6 \times 10^{4}$ and $2.1-7.3 \times 10^{3}$ cells ml $^{-1}$, respectively. In general, cell numbers decreased during the day from 07:00 to a minimum at 17:00 GMT, and subsequently increased during the night (Fig. 5b and c). Bacterial leucine incorporation rates ranged between 3.6-14 pmol leu $\mathrm{l}^{-1} \mathrm{~h}^{-1}$ and showed no obvious diel trends, although on average rates were slightly higher at night $\left(10.3 \pm 1.6 \mathrm{pmolleu}^{-1} \mathrm{~h}^{-1}\right)$ compared to the day $\left(8.4 \pm 2.6 \mathrm{pmol} \mathrm{leu} \mathrm{l}^{-1} \mathrm{~h}^{-1}\right)$, although they are not statistically different. Because we suspect from the $\mathrm{SF}_{6}$ data (Fig. 3a) that we drifted away from the assumed patch centre during the night, only times sampled during daylight hours (07:00-20:00 GMT, $n=14$ ) were included in subsequent statistical analysis. The only statistically significant relationship observed was between the uptake of methanol into cellular biomass and the numbers of Prochlorococcus cells $(n=14, r=0.7289, P \leq 0.01)$.

\subsection{Surface variability in methanol oxidation}

Apparent rate constants for methanol oxidation in surface (5$10 \mathrm{~m}$ ) waters of the NE Atlantic ranged from $0.006-0.39 \mathrm{~d}^{-1}$ (average of $0.09 \mathrm{~d}^{-1}, n=17$, Fig. 6). The continuous surface fluorometer onboard the ship was not working during the cruise, so we do not have in situ chlorophyll $a$ concentrations. However, surface estimates of $<0.2$ and between 0.3 $0.6 \mu \mathrm{g} l^{-1}$ for the $\mathrm{SF}_{6}$ patch area and higher chlorophyll $a$ sampling regions, respectively, were obtained from a composite Aqua-MODIS image over the duration of the cruise from 16 June to 16 July 2007 (Fig. 1). The average methanol oxidation rate constant in the lower chlorophyll $a$ sampling region was $0.065 \mathrm{~d}^{-1}(n=13)$, which more than doubled to $0.17 \mathrm{~d}^{-1}(n=4)$ in the higher chlorophyll area, although due to the large variability they are not statistically different. Bacterial leucine uptake ranged over an order of magnitude between 3.8-38.5 $\mathrm{pmoll}^{-1} \mathrm{~h}^{-1}$ (average of $11.6 \mathrm{pmoll}^{-1} \mathrm{~h}^{-1}$, $n=16$, Fig. 8). Interestingly, some relatively high bacterial leucine activities up to $39 \mathrm{pmoll}^{-1} \mathrm{~h}^{-1}$ were found in the lower chlorophyll surface waters. Surface methanol oxidation was not statistically related to bacterial leucine incorporation or the numbers of bacteria $\left(5-107 \times 10^{5} \mathrm{cells} \mathrm{ml}^{-1}\right)$, Prochlorococcus $\left(0.7-6.7 \times 10^{4}\right.$ cells ml $\left.^{-1}\right)$, or Synechococcus $\left(0.9-5.9 \times 10^{4}\right.$ cells $\left.\mathrm{ml}^{-1}\right)$.

\section{Discussion}

The average surface turnover time for methanol in the low chlorophyll $a$ waters was 15 days $(n=13)$, which compares to 6 days in the higher chlorophyll $a$ region. These values are 


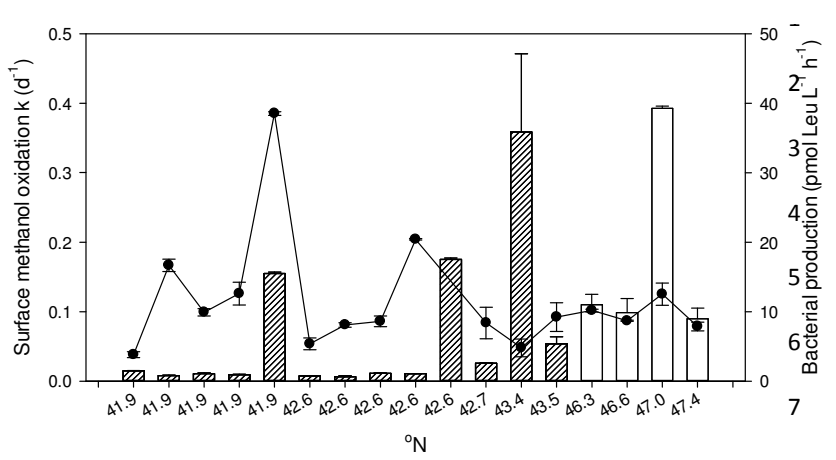

Fig. 6. (a) Spatial variability in methanol oxidation (apparent rate constant, $k$ ) in surface $(2-10 \mathrm{~m})$ waters with corresponding bacterial leucine uptake. The hashed bars indicate methanol oxidation with surface concentrations $<0.2 \mu g 1^{-1}\left(41-43^{\circ} \mathrm{N}\right)$, and the open bars chlorophyll $a$ between $0.3-0.6 \mu \mathrm{g} 1^{-1}\left(46-47^{\circ} \mathrm{N}\right)$. Error bars are based on at least 3 replicates.

within the ranges previously reported (Dixon et al., 2011a and $b$ ), but are higher than those sometimes found in ultralow chlorophyll $a$ regions $\left(0.003-0.006 \mu \mathrm{g}^{-1}, 1-5\right.$ days) of the tropical North Atlantic (Dixon et al., 2011a). The majority of methanol (92-99.8\%) in surface waters during the spatial survey was used as an energy source rather than a carbon source for cellular growth, which is typical of more oligotrophic North Atlantic waters (Dixon et al., 2011a). Bacterial growth efficiency for methanol $\left(\mathrm{BGE}_{\mathrm{m}}=\mathrm{G} /(\mathrm{G}+\mathrm{E}) \cdot 100\right)$ is summarised as a function of depth in Fig. 8 and suggests that in the top $0.25-25 \mathrm{~m}$ of the sunlit part of the water column the average $\mathrm{BGE}_{\mathrm{m}}$ is approximately $6 \%(0.4-26 \%)$, which compares to a BGE of $5 \pm 1 \%$ for open-ocean North Atlantic waters (Kirchman et al., 1991), $7 \pm 3 \%$ for the Sargasso Sea (Hansell et al, 1995) and between 1-8\% for the Bay of Biscay (González et al., 2003). Generally $\mathrm{BGE}_{\mathrm{m}}$ decreases with depth, in a similar pattern to that of BGE determined from bacterial production and respiration (e.g. Alonso-Sáez et al., 2007), which is normally considered a consequence of decreasing bacterial production with depth (e.g. Barbosa et al., 2001) with relatively constant bacterial respiration (del Giorgio et al., 2011). Although, the mean $\mathrm{BGE}_{\mathrm{m}}$ for microlayer$10 \mathrm{~cm}$ samples is less than that from the underlying $25-$ $217 \mathrm{~cm}$ layer, possibly implying that increasing environmental stress, e.g. UV, results in cellular increases in maintenance and repair costs, e.g. energy (del Giorgio et al., 2011; del Giorgio and Gasol, 2008; Carlson et al., 2007). Obernosterer et al. (2005) also reported enhanced community respiration rates in the surface microlayer compared to subsurface waters, whilst a depletion in dimethylsulfide at $10 \mathrm{~cm}$ depth compared to underlying waters was consistently reported by Zemmelink et al. (2005). Although, high outliers in $\mathrm{BGE}_{\mathrm{m}}$ of between $8-26 \%$, due to relatively high rates of methanol incorporated into cellular particulate material, suggest that hot spots of methylotrophic activity exist in the near-surface layers.
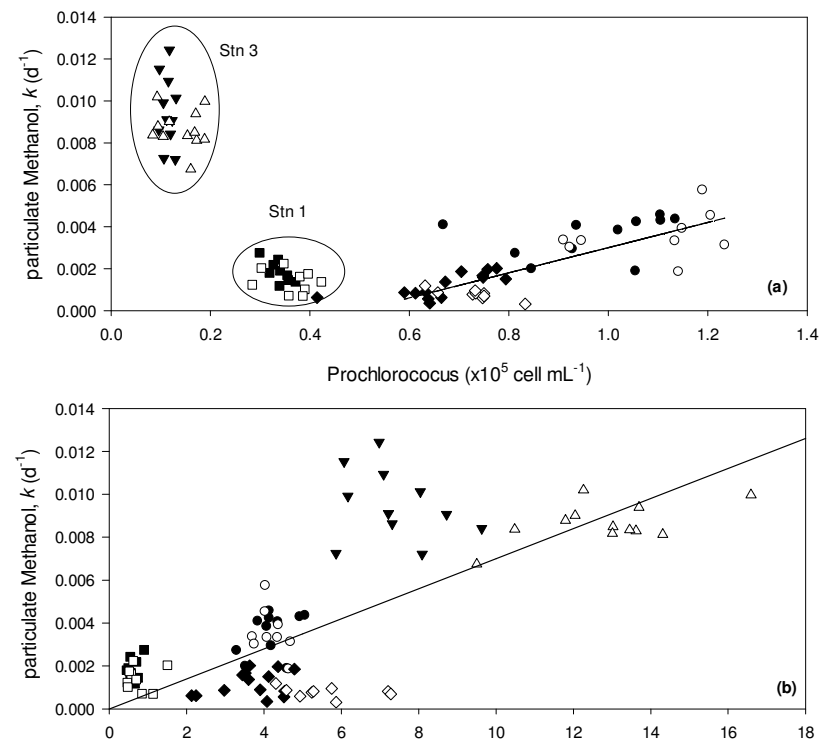

Synecococcus $\left(x 10^{3}\right.$ cells $\left.\mathrm{mL}^{-1}\right)$

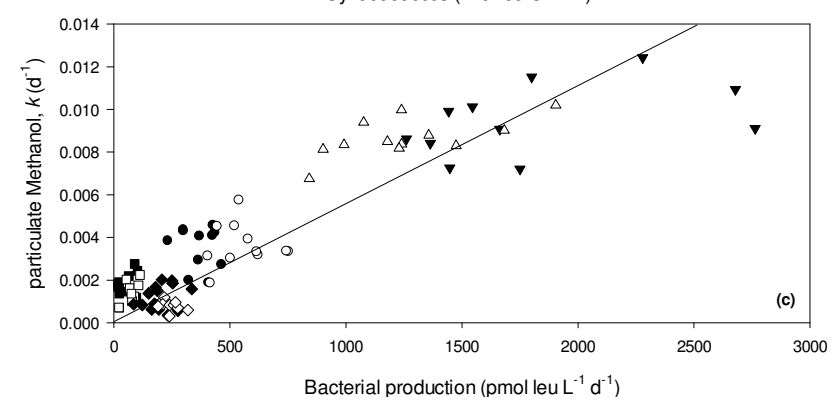

Fig. 7. Apparent rate constants $(k)$ for methanol uptake into the particulate phase as a function of the numbers of (a) Prochlorococcus and (b) Synechococcus cells for four spatially distinct diel experiments carried out in the NE Atlantic ( $\diamond$ and $\diamond$ this study, $\mathbf{\square}$ and $\square$ station 1 , $\circ$ and $\bullet$ station $2, \boldsymbol{\nabla}$ and $\Delta$ station 3 , refer to Table 1 ), where solid symbols denote day and open symbols night measurements.

Methanol oxidation rate constants from the diel experiment in this study are on average two orders of magnitude lower compared to those in the subtropical NE Atlantic (Dixon et al., 2011a), which may help explain why a temporal trend was not observed. In contrast, uptake into the particulate phase was comparable, particularly between this study and station 1 in the oligotrophic NE Atlantic (see Table 1 and Dixon et al., 2011a). However for particulate diel of this study, rates decreased during the day in a similar fashion to oxidation rates in Dixon et al. (2011a), which at present we do not fully understand.

The statistically significant relationship observed between the uptake of methanol into cellular biomass and the numbers of Prochlorococcus during the diel experiment could suggest that this abundant group of marine cyanobacteria is capable of mixotrophy using methanol as a carbon source for growth, although such correlations are not direct proof. 
Table 2. Summary of diel stations.

\begin{tabular}{|c|c|c|c|c|c|c|c|}
\hline & Date & Location & $\begin{array}{l}\text { Bacteria } \\
\left(\times 10^{5} \text { cells } \mathrm{ml}^{-1}\right)\end{array}$ & $\begin{array}{l}\text { Synechococcus } \\
\left(\times 10^{3} \text { cells ml }^{-1}\right)\end{array}$ & $\begin{array}{l}\text { Prochlorococcus } \\
\left(\times 10^{4}{\left.\text { cells } \mathrm{ml}^{-1}\right)}^{-1}\right.\end{array}$ & $\begin{array}{l}\text { Bacterial production } \\
\left(\text { pmol Leu } 1^{-1} h^{-1}\right)\end{array}$ & $\begin{array}{l}\text { Chl } a \\
\left(\mu \mathrm{g} 1^{-1}\right)\end{array}$ \\
\hline This study & 12 July 2007 & $42.7^{\circ} \mathrm{N} 16.1^{\circ} \mathrm{W}$ & $3.8-6.6$ & $2.1-7.3$ & $4.1-8.6$ & $3.6-14$ & $<0.20$ \\
\hline Stn $1^{\mathrm{a}}$ & 12 Dec 2007 & $26.1^{\circ} \mathrm{N} 23.6^{\circ} \mathrm{W}$ & $2.5-4.0$ & $0.5-1.5$ & $2.8-4.2$ & $0.8-4.7$ & 0.06 \\
\hline $\operatorname{Stn} 2^{\mathrm{a}}$ & 18 Nov 2007 & $17.7^{\circ} \mathrm{N} 22.9^{\circ} \mathrm{W}$ & $6.0-10.3$ & $3.3-5.1$ & $6.7-12.3$ & $9.9-32$ & 0.10 \\
\hline $\operatorname{Stn} 3^{\mathrm{a}}$ & 29 Nov 2007 & $16.0^{\circ} \mathrm{N} 23.7^{\circ} \mathrm{W}$ & $5.0-10.0$ & $5.9-16.6$ & $0.8-1.9$ & $36-118$ & 0.22 \\
\hline
\end{tabular}

a Stations from Dixon et al. (2011b).

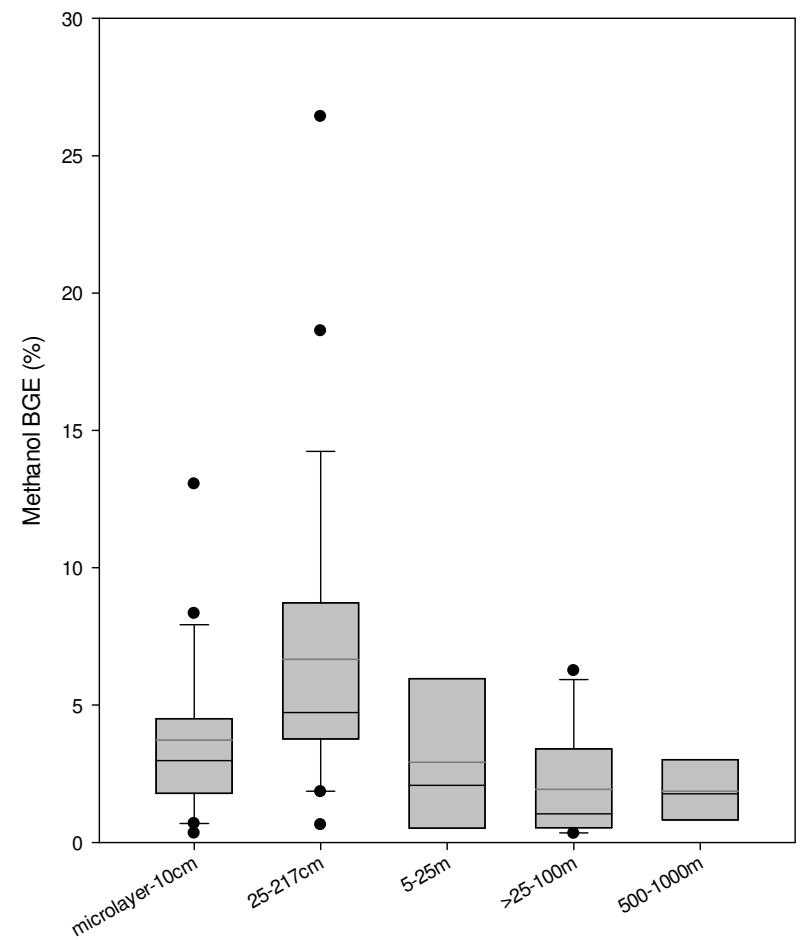

Fig. 8. Methanol bacterial growth efficiency with depth, where the shaded box represents the 25 th and 75 th percentile, the black line the mean, and the grey line the median growth efficiency. The error bars show the 10th and 90th percentile and $(\bullet)$ outlying points.

Zubkov and co-workers demonstrated that Prochlorococcus use organic nitrogen compounds, e.g. amino acids (Mary et al., 2008; Zubkov and Tarran, 2005; Zubkov et al., 2003, 2004), whilst sulphur uptake from dimethylsulfoniopropionate has also been demonstrated (Vila-Costa et al., 2006). The uptake of glucose by Prochlorococcus has also more recently been suggested by Gómez-Baena et al. (2008) as the first example of an organic molecule containing only carbon skeletons, i.e. no $\mathrm{N}, \mathrm{P}$ or $\mathrm{Fe}$, being assimilated presumably for cellular structures and/or to obtain reducing power. However, the lack of a statistically significant relationship between methanol oxidation rates (rather than uptake) and the numbers of Prochlorococcus suggest that methanol is being utilised for microbial growth and cellular incorporation rather than for energy generation. To test the robustness of this relationship further, we included the results from three other diel experiments (see Table 2 for data summary) that we have performed in more tropical regions of the northeast Atlantic (Fig. 7a, the methanol data have previously been published in Dixon et al. (2011a) but not in combination with the supporting microbial composition data). When the diel data from the present study are combined with station 2 from the subtropical northeast Atlantic, then a statistically significant linear relationship is found between methanol used as a carbon source for cellular growth during light and dark hours, i.e. for particulate methanol, and the numbers of Prochlorococcus cyanobacteria $(y=0.006 x-0.003, r=0.776, n=$ 45 for $P=0.001$, Fig. 7a). However station 1 , which is more oligotrophic in nature than station 2 and this study (see Table 2), has a higher particulate methanol uptake rate than expected from this relationship. This could imply that cells other than Prochlorococcus, e.g. methylotrophs, are dominating the uptake of methanol at this station, or perhaps microbial resources are more scarce, leading to enhanced reliance and uptake of methanol. Station 3 is located within the Cape Verde archipelago and is the most productive of these stations (see chlorophyll $a$ concentrations and bacterial production in Table 2). It is thus conceivable that methanol uptake in the particulate phase is dominated by very different microbes in this environment, where numbers of Prochlorococcus cells are very low and picoeukaryotic cells are more evident at $6-15 \times 10^{2}$ cells $\mathrm{ml}^{-1}$. The observed relationship between methanol uptake into particles and the numbers of Synechococcus is shown in Fig. $7 \mathrm{~b}$, which shows a broad but shallow gradient positive trend $(y=0.0007 x+0.0005$, $r=0.740, n=87$ for $P=0.001)$. There is significant scatter in the data evident, particularly for station 3 , which shows a positive deviation from the trend during daylight hours. Perhaps the most convincing relationship, in terms of $r$ value, is observed between methanol uptake and bacterial production for all the diel data (Fig. 7c), where $y=6 \times 10^{-6} x, r=$ $0.8789, n=87$ for $P=0.001$. No statistically significant linear relationships were found between methanol oxidation and bacterial production. However this is perhaps not surprising given that respiration of organic compounds is a much more stable process than biomass production (e.g. del Giorgio and Duarte, 2002), and these two processes are not always correlated in marine systems (e.g. Duarte et al., 2001). Perhaps an answer to the question posed in del Giorgio and 
Table 3. Summary of microbial methanol uptake and oxidation.

\begin{tabular}{|c|c|c|c|c|c|c|c|}
\hline & Spatial & Diel (24 h) & $\mu$ layer $-10 \mathrm{~cm}$ & $25 \mathrm{~cm}-2 \mathrm{~m}$ & $5-25 \mathrm{~m}$ & $>25-100 \mathrm{~m}$ & $500-1000 \mathrm{~m}$ \\
\hline \multicolumn{8}{|c|}{$\begin{array}{l}\text { Methanol } \\
\text { oxidation }\left(\mathrm{d}^{-1}\right)\end{array}$} \\
\hline Range & $0.006-0.392$ & $0.007-0.023$ & $0.002-0.589$ & $0.004-0.367$ & $0.007-0.359$ & $0.009-0.275$ & $0.007-0.008$ \\
\hline $\mathrm{Av} \pm 1 \mathrm{sd}$ & $0.090 \pm 0.121$ & $0.014 \pm 0.004$ & $0.093 \pm 0.192$ & $0.039 \pm 0.075$ & $0.059 \pm 0.108$ & $0.059 \pm 0.096$ & $0.008 \pm 0.000$ \\
\hline$n$ & 17 & 23 & 21 & 27 & 10 & 12 & 3 \\
\hline$c v(\%)$ & 133 & 29 & 208 & 190 & 183 & 162 & 2.9 \\
\hline \multicolumn{8}{|c|}{$\begin{array}{l}\text { Particulate } \\
\text { methanol }\left(\mathrm{d}^{-1}\right)\end{array}$} \\
\hline Range & $<0.001-0.017$ & $<0.001-0.002$ & $<0.001-0.004$ & $<0.001-0.084$ & $<0.001-0.012$ & $<0.001-0.014$ & $<0.001$ \\
\hline $\mathrm{Av} \pm 1 \mathrm{sd}$ & $0.007 \pm 0.005$ & $0.001 \pm 0.001$ & $0.001 \pm 0.001$ & $0.005 \pm 0.016$ & $0.002 \pm 0.004$ & $0.002 \pm 0.004$ & $<0.001$ \\
\hline$n$ & 11 & 24 & 21 & 27 & 10 & 18 & 3 \\
\hline$c v(\%)$ & 73 & 50 & 138 & 308 & 184 & 216 & 57 \\
\hline
\end{tabular}

Duarte, 2002 "what are the sources of organic matter that fuel these relatively high rates of respiration in the surface waters of oligotrophic oceans?" could be partially addressed by looking at respiration of methanol and other biologicallyreactive oxygenated volatile organic compounds, especially given the high nanomolar concentrations of methanol in the North Atlantic gyre (up to $429 \mathrm{nM}$, Beale et al., 2011; Dixon et al., 2011b). However what remains elusive is the source(s) of methanol in the North Atlantic gyre, given that the air-tosea flux is estimated to be very low in these regions (Dixon et al., 2011b), and methanol oxidation rates are measurable below the mixed layer down to depths of $1000 \mathrm{~m}$.

Some very high methanol oxidation rate constants of $0.5-$ $0.6 \mathrm{~d}^{-1}$ were sporadically found in the microlayer and immediately underlying waters $(10 \mathrm{~cm})$. These values compare favourably to a diel range of $0.3-0.8 \mathrm{~d}^{-1}$ reported for surface waters of a very oligotrophic station (chlorophyll $a$ concentration of $0.06 \mu \mathrm{g}^{-1}$ ) in the tropical North Atlantic (station 1, Dixon et al., 2011b). Methanol oxidation rates in the sea surface microlayer exhibited the greatest heterogeneity of all samples, showing a ca. 300-fold difference between minimum and maximum values. This compares with a 3fold difference shown in surface waters over the diel cycle, from a station with similar background biogeochemical characteristics (Fig. 1, $\mathrm{SF}_{6}$ patch area), and a 65 -fold difference between surface seawater of variable chlorophyll $a$ concentrations (Fig. 6). Particulate methanol uptake into particles in the microlayer was generally low at $\leq 0.001 \mathrm{~d}^{-1}$, but also exhibited more heterogeneity compared to bulk surface $(\sim 5 \mathrm{~m})$ seawater over diel (Fig. 5) or spatial trends (Dixon et al., 2011b). This average methanol uptake into particles is lower than previously reported for surface waters $(\sim 0.001-$ $0.012 \mathrm{~d}^{-1}$, Dixon et al., 2011b), although within the range reported in the diel experiment of the present study (Fig. 5). These results indicate that microbial use of methanol for incorporation into cellular structures in the microlayer was generally very low, but on occasion comparable to the low- est estimated reports for surface waters (where chlorophyll $a$ concentrations were $<0.2 \mu \mathrm{g} \mathrm{I}^{-1}$ ).

Numbers of bacteria, Prochlorococcus and picoeukaryote cells in the microlayer and underlying layer $(10 \mathrm{~cm})$ were within ranges of our surface diel (Fig. 5) and spatial survey (Fig. 6). Whilst the range in Synechococcus cell numbers in the microlayer and $10 \mathrm{~cm}$ layer agreed with surface water samples over a large spatial scale (Fig. 6), they were on average higher than those reported during our diel experiment (Fig. 5).

Higher average microbial rates of methanol oxidation and uptake into particles were determined in surface waters sampled over a wide spatial range (Table 3, chlorophyll $a$ ranging from $<0.2-0.6 \mu \mathrm{g}^{-1}$ ) compared to diel sampling at one location (chlorophyll $a<0.2 \mu \mathrm{g} \mathrm{I}^{-1}$ ), where for methanol oxidation $\mathrm{t}_{\mathrm{ox}}=3.03\left(\mathrm{t}_{38}=2.68\right.$ for $\left.P=0.01\right)$ and particulate $\mathrm{t}_{\mathrm{part}}=5.72\left(\mathrm{t}_{33}=2.75\right.$ for $\left.P=0.01\right)$. Additionally, greater variability is evident over wider spatial sampling scales compared to diel sampling at one location, particularly for methanol oxidation ( $c v=133 \%$ and $29 \%$, respectively, Table 1) $\left(F_{o x}=915\right.$ where $F_{16,22}=2.978$, and $F_{\text {part }}=25$ where $\mathrm{F}_{23,10}=3.168$ and $P=0.01$ for spatial compared to diel samples).

The average methanol oxidation and particulate rates determined in the microlayer $-10 \mathrm{~cm}$ compared to the $0.25-$ $2 \mathrm{~m}$ depth were statistically the same (Table $3, \mathrm{t}_{\mathrm{ox}}=1.34$, $\mathrm{t}_{\text {part }}=1.14, \mathrm{t}_{46}=2.75$ and $P=0.01$ ), due to the large sample variance. However for methanol oxidation a two-sided Ftest $\left(\mathrm{F}=6.55, \mathrm{~F}_{21,27}=2.78, P=0.01\right)$ suggests that there is more variability in the microlayer- $10 \mathrm{~cm}$ compared to 0.25 $2 \mathrm{~m}$. In contrast, more variability in particulate methanol uptake rates was shown in the $0.25-2 \mathrm{~m}$ compared to the microlayer $-10 \mathrm{~cm}$ sampling depths $\left(\mathrm{F}=256, \mathrm{~F}_{20,26}=2.78\right.$ for $P=0.01$ ).

The average methanol oxidation and particulate rates determined in the $0.25-2 \mathrm{~m}, 5-25 \mathrm{~m}$ and $>25-100 \mathrm{~m}$ clearly show no differences, e.g. $\mathrm{t}_{\mathrm{ox}}=0.638, \mathrm{t}_{\text {part }}=0.580, \mathrm{t}_{35}=$ 
2.75 and $P=0.01$, when comparing $0.25-2 \mathrm{~m}$ with $5-25 \mathrm{~m}$ rates (see Table 3 ). The only statistically significant difference in variability was shown for the uptake of methanol into the particulate phase between the $0.25-2 \mathrm{~m}$ and $5-25 \mathrm{~m}$ depths $\left(F=16, \mathrm{~F}_{26,9}=3.18\right.$ for $\left.P=0.01\right)$. Methanol oxidation and uptake rate constants were notably low for deepocean samples between $500-1000 \mathrm{~m}$ compared to depths $\leq 100 \mathrm{~m}$.

\section{Conclusions}

Average surface methanol oxidation rates range between $0.006-0.39 \mathrm{~d}^{-1}$ and agree with those previously published. Some relatively high methanol oxidation rate constants of $0.5-0.6 \mathrm{~d}^{-1}$ were sporadically found in the microlayer and immediately underlying waters $(10 \mathrm{~cm})$, although rates were highly variable. Methanol uptake into the particulate phase was exceptionally low in microlayer samples and at depths between $500-1000 \mathrm{~m}$, suggesting that any methanol utilised by microbes in this environment is for energy generation. The microlayer and $10 \mathrm{~cm}$ depths showed a higher proportion of bacteria with a relatively low DNA content, and bacterial leucine uptake rates in surface microlayer samples were either less than (for 6 out of 8 occasions) or the same as those in the underlying $10 \mathrm{~cm}$ layer. Statistically the average methanol oxidation and particulate rates were the same throughout the water column, despite often demonstrating subsurface peaks, due to high variability in the data. Particulate methanol uptake showed highest variability in the 0.25-2 $\mathrm{m}$ top layer compared to all other depths sampled. The statistically significant relationship between the uptake of methanol into particles and bacterial leucine incorporation suggests that perhaps many heterotrophic bacteria can use methanol as a carbon source for cellular growth. On average, $\mathrm{BGE}_{\mathrm{m}}$ in the top $25 \mathrm{~m}$ of the water column is $6 \%$ and decreases with depth. Although, for microlayer and $10 \mathrm{~cm}$-depth samples, $\mathrm{BGE}_{\mathrm{m}}$ is less than the near-surface $25-217 \mathrm{~cm}$, possibly reflecting increased environmental UV stress resulting in increased maintenance costs, i.e. energy required for survival. We conclude that microbial methanol use, i.e. loss of methanol from seawater, is highly variable, particularly close to the seawater surface, which could significantly impact upon seawater concentrations and hence the air-sea flux. Further investigations should focus on identifying what controls this variability and specifically understanding which marine organisms use methanol for energy and/or for carbon assimilation. We feel that this could be key to understanding methanol loss patterns and even the magnitude and direction of the methanol flux across the sea surface.

Acknowledgements. We thank H. Zemmelink, J. Cluderay and H. Slagter from the Royal Netherlands Institute for Sea Research for the provision of seawater samples from their Catamaran near surface sampler, and the scientists, officers and crew of the RRS
Discovery for their help during the UK SOLAS research cruises DOGEE (Deep Ocean Gas Exchange Experiment). We also thank R. Beale for her help in sampling during the Diel experiment and G. Tarran for his help with the flow cytometry analysis. Satellite data were processed by the NERC Earth Observation Data Acquisition and Analysis Service (NEODAAS) at Plymouth Marine Laboratory (http://www.neodaas.ac.uk). This study was supported by the UK Natural Environmental Research Council (NERC) via UK SOLAS and Oceans 2025 funding for Plymouth Marine Laboratory.

Edited by: G. Herndl

\section{References}

Alonso-Sáez, L., Gasol, J. M., Arístegui, J., Vilas, J. C., Vaqué, D., and Duarte, C. M.: Large scale variability in surface bacterial carbon demand and growth efficiency in the subtropical northeast Atlantic Ocean, Limnol. Oceanogr., 52, 533-546, 2007.

Barbosa, A. B., Galvão, H. M., Mendes, P. A., Álvarez-Salgado, X. A., Figueiras, F. G., and Joint. I.: Short-term variability of heterotrophic bacterioplankton during the upwelling off the NW Iberian margin, Prog. Oceanogr., 51, 339-359, 2001.

Beale, R., Liss, P. S., and Nightingale, P. D.: First oceanic measurements of ethanol and propanol, Geophys. Res. Lett., 37, L24607, doi:10.1029/2010GL045534, 2010.

Beale, R., Liss, P. S., Dixon, J. L., and Nightingale, P. D.: Quantification of oxygenated volatile organic compounds in seawater by membrane inlet-proton transfer reaction/mass spectrometry, Anal. Chim. Acta, 706, 128-134, doi:10.1016/j.aca.2011.08.023, 2011.

Brooks, I. M., Yelland, M. J., Upstill-Goddard, R. C., et al. (54 authors): Physical exchanges at the air-sea interface, UK-SOLAS Field Measurements, B. Am. Meteorol. Soc., 5, 629-644, 2009.

Carlson, C. A., del Giorgio, P. A., and Herndl, G. J.: Microbes and the dissipation of energy and respiration: From cells to ecosystems, Oceanogr., 20, 61-73, 2007.

Carpenter, L. J., Lewis, A., Hopkins, J. R., Read, K. A., Longley, I. D., and Gallagher, M. W.; Uptake of methanol to the North Atlantic Ocean surface, Global Biogeochem. Cy., 18, GB4027, doi:10.1029/204GB002294, 2004.

Chistoserdova, L.: Modularity of methylotrophy, revisited, Environ. Microbiol., 13, 2603-2622, doi:10.1111/j.14622920.2011.02464.x, 2011.

Cunliffe, M., Salter, M., Mann, P. J., Whiteley, A. S., UpstillGoddard, R. C., and Murrell, J. C.: Dissolved organic carbon and bacterial populations in the gelatinous surface microlayer of a Norwegian fjord mesocosm, FEMS Microbiol. Lett, 299, 248254, 2009.

del Giorgio, P. A. and Duarte, C. M.: Respiration in the open ocean, Nature, 420, 379-384, 2002.

del Giorgio, P. A. and Gasol, J. M.: Microbial ecology of the oceans, edited by: Kirchman, D. L., 2nd edition, Wiley, New Jersey, USA, 243-298, 2008.

del Giorgio, P. A., Condon, R., Bouvierm, T., Longnecker, K., Bouvier, C., Sherr, E., and Gasol, J. M.: Coherent patterns in bacterial growth, growth efficiency, and leucine metabolism along a northeastern Pacific inshore-offshore transect, Limnol. Oceanogr., 56, 1-16, 2011. 
Dixon, J. L., Beale, R., and Nightingale, P. D.: Microbial methanol uptake in northeast Atlantic waters, ISME J., 5, 704-716, $2011 \mathrm{a}$.

Dixon, J. L., Beale, R., and Nightingale, P. D.: Rapid biological oxidation of methanol in the tropical Atlantic: significance as a microbial carbon source, Biogeosciences, 8, 2707-2716, doi:10.5194/bg-8-2707-2011, 2011b.

Duarte, C. M., Agustí, S., Arístegui, J., González, N., and Anadón, R.: Evidence for a heterotrophic subtropical northeast Atlantic, Limnol. Oceanogr., 46, 425-428, 2001.

Garrett, W. D.: Collection of slick-forming materials from the sea surface, Limnol. Oceanogr., 10, 602-605, 1965.

Gómez-Baena, G., López-Lozano, A., Gil-Martínez, J., Lucena, M. J., Diez, J., Candau, P., and García-Fernández, J. M.: Glucose uptake and its effect on gene expression in Prochlorococcus, PLoS ONE, 3, e3416, doi:10.1371/journal.pone.0003416, 2008.

González, N. R., Anadón, R., and Viesca, L.: Carbon flux through the microbial community in a temperate sea during summer: role of bacterial metabolism, Aquat. Microb. Ecol., 33, 117-126, 2003.

Hansell, D. A., Bates, N. R., and Gundersen, K.: Mineralization of dissolved organic carbon in the Sargasso Sea. Mar. Chem., 51, 201-212, 1995.

Jacob, D. J., Field, B. D., Li, Q., Blake, D. R., de Gouw, J., Warneke, C., Hansel, A., Wisthaler, A., Singh, H. B., and Guenther, A.: Global budget of methanol: Constraints from atmospheric observations, J. Geophys. Res., 110, D08303, doi:10.1029/2004JD005172, 2005.

Kirchman, D. L., Suzuki, Y., Garside, C., and Ducklow, H. W.: High turnover rates of dissolved organic carbon during a spring phytoplankton bloom, Nature, 352, 612-614, 1991.

Lewis, A. C., Hopkins, J. R., Carpenter, L. J., Stanton, J., Read, K. A., and Pilling, M. J.: Sources and sinks of acetone, methanol, and acetaldehyde in North Atlantic marine air, Atmos. Chem. Phys., 5, 1963-1974, doi:10.5194/acp-5-1963-2005, 2005.

Mary, I., Tarran, G. A., Warwick, P. E., Terry, M. J., Scanlan, D. J., Burkill, P. H., and Zubkov, M. V.: Light enhanced amino acid uptake by dominant bacterioplankton groups in surface 10 waters of the Atlantic Ocean, FEMS Microbiol. Ecol., 63, 36-45, 2008.

Murrell, C. J. and McDonald, I. R.: Encyclopedia of Microbiology, edited by: Lederberg, J., 3, 245-255, Academic Press, London, UK, 2000.

Neufeld, J. D, Schäfer, H, Cox, M. J, Boden, R., McDonald, I. R., and Murrell, J. C.: Stable-isotope probming implicates Methylophaga spp abd novel Gammaproteobacteria in marine methanol and methylamine metabolism, ISME J., 1, 480-491, 2007.

Neufeld, J. D., Chen, Y., Dumont, M. G., and Murrell, C. J.: Marine methylotrophs revealed by stable-isotope probing, multiple displacement amplification and metagenomics, Environ. Microbiol., 10, 1526-1535, 2008.

Obernosterer, I., Catala, P., Reinthaler, T., Herndl, G. J., and Lebaron, P.: Enhanced heterotrophic activity in the surface microlayer of the Mediterranean Sea, Aquat. Microb. Ecol., 39, 293-302, 2005.

Salter, M. E., Uptsill-Goddard, R. C., Nightingale, P. D., Archer, S. D., Blomquist, B., Ho, D. T., Huebert, B., Schlosser, P., and Yang, M.: Impact of an artificial surfactant release on air-sea gas fluxes during Deep Ocean Gas Exchange Experiment II, J. Geophys. Res., 116, C11016, doi:10.1029/2011JC007023, 2011.
Singh, H. B. Chen, Y., Tabazadeh, A., Fukui, Y., Bey, I., Yantosca, R., Jacob, D., Arnold, F., Wohlfrom, K., Atlas, E., Flocke, F., Blake, D., Blake, N., Heikes, B., Snow, J., Talbot, R., Gregory, G., Sachse, G., Vay, S., and Kondo, Y.: Distribution and fate of selected oxygenated organic species in the troposphere and lower stratosphere over the Atlantic, J. Geophys. Res., 105, 3795-3805, 2000.

Singh, H. B., Chen, Y., Staudt, A., Jacob, D., Blake, D., Heikes, B., and Snow, J.: Evidence from the Pacific troposphere for large global sources of oxygenated organic compounds, Nature, 410, 1078-1081, 2001.

Singh, H. B., Tabazadeh, A., Evans, M. J., Field, B. D., Jacob, D. J., Sachse, G., Crawford, J. H., Shetter, R., and Brune, W. H.: Oxygenated volatile organic chemicals in the oceans: Inferences and implications based on atmospheric observations and air-sea exchange models, Geophys. Res. Lett., 30, 1862, doi:10.1029/2003GL017933, 2003.

Sinha, V., Williams, J., Meyerhöfer, M., Riebesell, U., Paulino, A. I., and Larsen, A.: Air-sea fluxes of methanol, acetone, acetaldehyde, isoprene and DMS from a Norwegian fjord following a phytoplankton bloom in a mesocosm experiment, Atmos. Chem. Phys., 7, 739-755, doi:10.5194/acp-7-739-2007, 2007.

Smith, D. C. and Azam, F.: A simple, economical method for measuring bacterial protein synthesis rates in seawater using ${ }^{3} \mathrm{H}-$ leucine, Mar. Microb. Food Webs, 6, 107-114, 1992.

Sun, J., Steindler, L., Thrash, J. C., Halsey, K. H., Smith, D. P., Carter, A. E., Landry, Z. C., and Giovannoni, S. J.: One carbon metabolism in SAR11 pelagic marine bacteria, PLoS ONE, 6, e23973, doi:10.1371/journal.pone.0023973, 2011.

Tilstone, G. H., Airs, R. L., Martinez-Vicente, V., Widdicombe, C., and Llewellyn, C.: High concentrations of mycosporine-like amino acids and coloured dissolved organic matter in the sea surface microlayer off the Iberian Peninsula, Limnol. Oceanogr., 55, 1835-1850, 2010.

Villa-Costa, M., Simo, R., Harada, H., Gasol, J. M., Slezak, D., and Kiene, R. P.: Dimethylsulfoniopropionate uptake by marine phytoplankton, Science., 314, 652-654, 2006.

Williams, J., Holzinger, R., Gros, V., Xu, X., Atlas, E., and Wallace, D. W. R.: Measurements of organic species in air and seawater from the topical Atlantic, Geophys. Res. Lett., 31, L23S06, doi:10.1029/2004GL020012, 2004.

Zemmelink, H. J., Houghton, L., Sievert, S. M., Frew, N. M., and Dacey, J. W. H.: Gradients in dimethylsulfide, dimethylsulfoniopropionate, dimethylsulfoxide, and bacteria near the surface, Mar. Ecol. Prog. Ser., 295, 33-42, 2005.

Zubkov, M. V. and Tarran, G. A.: Amino acid uptake of Prochlorococcus spp. in surface waters across the South Atlantic Subtropical Front, Aquat. Microb. Ecol., 40, 241-249, 2005.

Zubkov, M. V., Fuchs, B. M., Tarran, G. A., Burkhill, P. H., and Amann, R.: High rate of uptake of organic compounds by Prochorococcus cyanobacteria as a key to their dominance in oligotrophic oceanic waters, Appl. Environ. Microbiol., 69, 12991304, 2003.

Zubkov, M. V., Tarran, G. A., and Fuchs, B. M.: Depth related amino acid uptake by Prochorococcus cyanobacteria in the Southern Atlantic tropical gyre, FEMS Microbiol. Ecol., 50, 153-161, 2004. 
Zuev, B. K., Chudinova, V. V., Kovalenko, V. V., and Yagov, V. V.: The conditions of formation of the chemical composition of the sea surface microlayer and techniques for studying organic matter in it, Geochem. Int., 39, 702-710, 2001. 